
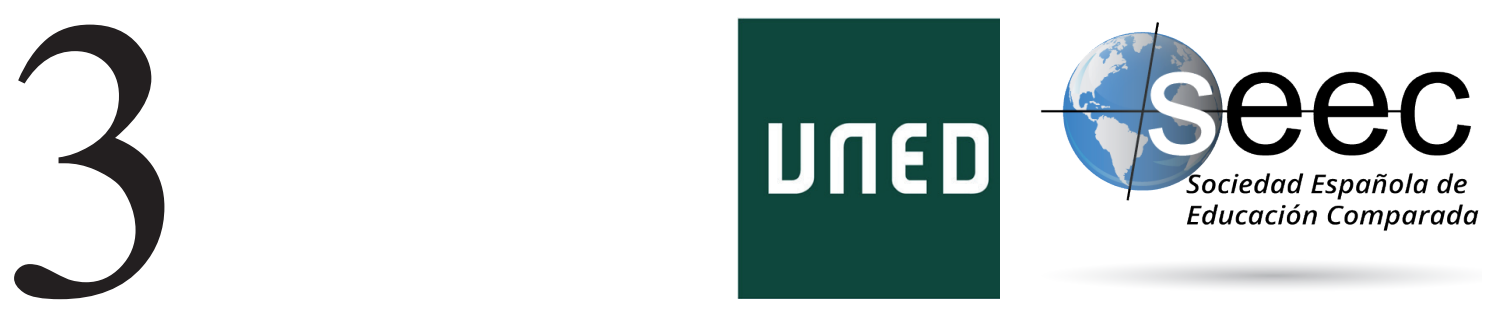

\title{
Empires, Rituals and Ceremonial Pedagogy, Old and New
}

Imperios, rituales y pedagogía ceremonial, lo antiguo y lo nuevo

\section{Anselmo R. Paolone*}

DOI: $10.5944 /$ reec.31.2018.21588

\section{Recibido: 12 de marzo de 2018 Aceptado: 18 de abril de 2018}

\footnotetext{
*Anselmo R. Paolone: Ph.D. at the European University Institute in Florence, has been Visiting Global Fellow at New York University; Visiting Researcher at the London School of Economics and member of the équipe ERASME of CNRS. He is currently tenured researcher at the University of Udine, Italy. He is Board Member of the Italian Comparative Education Association (SICESE). Some of his recent works are: Accademica o applicata? Educazione comparata, convergenze-divergenze globali e etnografia nella comtemporaneità (2016); Comparative education in an age of crisis. Challenges and opportunities in contemporary Italy (2016). Datos de contacto: E-mail: anselmo.paolone@uniud.it
} 


\begin{abstract}
In the Roman Empire, the function of creating part of the common culture needed for citizenship was carried out by institutions different from what we call today a "school system". It was the ancient society in its entirety, via its vast ritual apparatus, which provided an equivalent of what we call today "civic education". In the universal Roman Empire all citizens were educated by the means of such "ceremonial pedagogy." It was a form of collective education, based on symbols and actions that could "talk" a universal language to the varied ethnic identities of the citizens. Similarly the Roman Catholic Church (heir to the universality of the Roman Empire) also uses art, architecture, rituals and symbols to educate the universal crowd of the faithful. There is one group of Roman rituals in particular (adventus, amburbium, lustrum), based on the stately procession, whose ties with the education of citizens are evident. The paper will explore such educational dimensions of the rituals, in what it is believed to be one of their surviving forms of today, the Roman Catholic procession of the patron saint, which was studied ethnographically in a village in central Italy. In Castelfiocco, a village noted for its campanilismo (strong sentiment of local membership) a ritual system based on the cult of saints conveys to the population values which are survivors of an older political order in which the modern, comprehensive nation-state had not yet appeared. In this traditional system the dialectic is not between locality and nation-state, but between local membership and the universality of the Church. The understanding of some aspects of such traditional dialectic, and especially the understanding of the way in which it is conveyed to the population by rituals used as ceremonial pedagogy, is of renewed interest in our age of globalisation.
\end{abstract}

Key Words: Comparative Education; Rituals of the Roman Empire; Roman Catholic Rituals; Ceremonial Pedagogy; Ethnography of Education; Informal education

\title{
Resumen
}

En el Imperio Romano, la función de crear parte de la cultura común necesaria para la ciudadanía, fue llevada a cabo por instituciones diferentes de lo que hoy llamamos «sistema escolar». Fue la sociedad antigua en su totalidad, a través de su vasto aparato ritual, la que proporcionó algo equivalente de lo que hoy llamamos «educación cívica». En el Imperio Romano universal, todos los ciudadanos eran educados por medio de esa «pedagogía ceremonial». Era una forma de educación colectiva, basada en símbolos y acciones que pudiesen «hablar» un lenguaje universal a los ciudadanos de diversas identidades étnicas. Del mismo modo que la Iglesia Católica Romana (heredera de la universalidad del Imperio Romano) también ha utilizado el arte, la arquitectura, los rituales y los símbolos para educar a los fieles de todo el orbe. Hay un grupo de rituales romanos en particular (adventus, amburbium, lustrum), basados en majestuosas procesiones, cuyos vínculos con la educación de los ciudadanos son evidentes. El artículo explorará tales dimensiones educativas de los rituales, en lo que se cree que es una de sus formas supervivientes hoy, la procesión católica romana del santo patrón, la cual fue estudiada etnográficamente en un pueblo del centro de Italia. En Castelfiocco, un pueblo famoso por su campanilismo (fuerte sentimiento de pertenencia local), un sistema ritual basado en el culto a los santos, transmite a la población valores que sobreviven de un orden político más antiguo en el que el estado-nación moderno y global todavía no había aparecido. En este sistema tradicional, la dialéctica no es entre la localidad y la nación-estado, sino entre los miembros de la localidad y la universalidad de la Iglesia. La comprensión de algunos aspectos de tal dialéctica tradicional, y especialmente la comprensión de la forma en que se transmite a la población mediante rituales utilizados como pedagogía ceremonial, es de renovado interés en nuestra era de globalización.

Palabras clave: Educación comparada; Rituales del Imperio Romano; Rituales católicos romanos; Pedagogía ceremonial; Etnografía de la educación; Educación no formal 


\section{Rituals as "informal education" in the Roman Empire}

In this paper I will try to show how some aspects of the rituals of the Roman Empire ${ }^{1}$, which have been studied from many different points of view (political, religious, anthropological, etc.) are in fact relevant to comparative education studies. There is one group of rituals in particular, based on the stately procession: the imperial adventus, and two older rituals (the amburbium and the lustrum, which have elements in common with the former) whose ties with the education of citizens are evident (Paolone 2014, 2016; MacCormack 1972, 1995). In this paper I will try to explore such educational dimensions of the rituals, both in their original form, (back in the days of the Roman Empire), and especially in what I believe to be one of their surviving forms of today, which I have studied through fieldwork, in a village in central Italy. In fact, this paper is also about social memories of rituals and their retention and re-location within new meaning systems. The discussion of such themes can show us that in today's world several elements from empires of the past are still surviving and that, by studying their relationship to the new context, we can deepen our understanding of today's world (in this specific case: of today's education).

If the school system (one of the bases of what we call today: formal education) seems to be a characteristic of the modern nation-state (Soldani and Turi 1997, Archer 1979) then it appears to be a less important and systematic feature in some older forms of sovereignty, including the Roman Empire.

The Roman Empire for instance had no state school system (with the exception of a few smaller institutions, at least until Vespasian²) (Marrou 1948).

As I have already shown (Paolone 2014, 2016) in Rome the function of creating the common culture needed for citizenship, was carried out by institutions different from what we call today a "school system".

It was the ancient society in its entirety, via its vast ritual apparatus, which provided an equivalent of what we call today "civic education".

In particular, the ritual apparatus of the Roman Empire was huge, magnificent, sophisticated, and articulated in terms of a sort of ancient intelligence (Jaynes 1977) which leans towards myth and the unconscious (rather than the scientific rationality of Enlightenment -which dominates modern schooling).

$1 \quad$ By Empire I mean the post-republican period of the ancient Roman civilization, characterised by government headed by Emperors, and large territorial holdings in Europe, Asia and Africa, (over 5 million sq $\mathrm{km}$ at its greatest extent, around $117 \mathrm{AD}$ ). When in $27 \mathrm{BC}$ the Roman Senate formally granted Octavian overarching power and the new title of Augustus, the 500-year-old republican institutions (which had assured constant territorial expansion to the Roman state and, for at least three centuries, political stability and the steady cultural assimilation of conquered or allied cities), began to lose their power. Progressively the Emperors assumed for themselves the powers and prerogatives of the ancient republican magistrates and institutions, including some of those pertaining to the Senate. Under many aspects, there is a substantial continuity between the late Republic and the first period of the Empire, at least until the second century AD. In $\mathrm{AD} 395$ Emperor Teodosius divided the Empire in two parts: the Western, which lasted until $476 \mathrm{AD}$, and the Eastern, which ended in 1453 AD.

2 Emperor from 69 to $79 \mathrm{AD}$, in his military career he had played an important role in the Roman invasion of Britain in $43 \mathrm{AD}$ and in the subjugation of Judaea during the Jewish rebellion of $66 \mathrm{AD}$. In his ten-year rule, he reformed the financial system at Rome and initiated several construction projects, including the building of the Flavian Amphitheatre, better known as the Colosseum. 
The impressive width and scope (and pageant) of such a ritual apparatus is evident in comprehensive descriptions such as Ovid's ${ }^{3}$ Fasti (The Book of Days).

Rituals of the Roman Empire where "total social facts" which involved the whole of society not only in terms of the citizens and their behaviour (conscious or unconscious), opinions and values, but also in terms of the physical infrastructures and spaces of the Roman cities. As has been shown (Zanker 1989), architecture and city-planning were functional elements of this ritual apparatus.

Most public spaces were built with an eye to the functions they played in the complex and endless sequence of Imperial rituals. This ritual/visual/architectural communicative effort of the Emperor was also aimed at maintaining that consensus on which Roman political life was based and which assured the loyalty to Empire of local communities (Ando 2000) ${ }^{4}$.

In my judgement, this was not "spectacle" in the same meaning that some post-foundational and critical authors have exposed today, talking about contemporary society (Hardt and Negri 2000, Novoa and Yariv-Mashal 2003). This was rather "ceremonial pedagogy" (Schriewer 2009).

In fact, the postmodern logic of spectacle as an instrument to manipulate the masses is tied to the dislocation of the organisational dynamic of sovereignty from the ancient and medieval terrain of hierarchy to that of modern discipline, from command to function. Max Weber and Michel Foucault have insisted on these metamorphoses in the sociological figures of power.

But in the Roman Empire, which was in many ways a holistic, hierarchical society5, sovereignty was rooted in transcendence, and the form of belief which citizens had in such rituals (as the processional ones we will describe in this paper) was in my judgement different from the "belief" of citizens, which modern powers manipulate.

The ancient belief which was implied in participating in imperial rituals was in fact shared by most of the hierarchical degrees of command in society (social orders) including the Emperor ${ }^{6}$ (Zanker 1989: 159-167).

Furthermore, as we shall see in the following pages, the different social actors involved in these kinds of rituals added (and add) their own modifications and symbols to them, which shows that they are active parts in them, and contribute to the final meaning of the rites, which are thus "living collective creations", constitutive of various aspects of society.

Thus in the Roman Empire, citizens were participating in rituals within another form of belief and devotion, which went beyond the ways by which modern powers subjugate and condition individuals.

In ancient holistic societies, the rituals overlapped with everyday social life, as ancient individuals were not morally autonomous, unlike their modern counterparts (Constant 1819). They had no "private life" in the modern meaning, and all they did was, in a sense,

3 Publius Ovidius Naso (43 BC-17 AD), was a Roman poet who lived during the reign of Augustus. A contemporary of Virgil and Horace, with whom is portrayed by some as one of the three greatest poets of Latin literature, at the peak of popularity Ovid was sent by Augustus into exile in a remote province, until his death. He is today best known for the Metamorphoses, a 15-book mythological narrative, and for works in elegiac couplets such as Ars Amatoria, and Fasti: the latter is a vast description of Rome's rituals.

4 C. Ando especially dedicates chapter 6 of his book to elucidate the "social dramas" that implicitly or explicitly invoked the consensus of provincials, while chapter 7 explores some of the symbolic aspects of Roman power, both visual and ritual.

$5 \quad$ I use here the terms holistic society and hierarchical society in the meaning of Louis Dumont (1966) 6 Augustus re-established the mos majorum (morality of the forefathers) in the Empire, not as a cynical and detached modern ruler would do (e.g. Putin restoring Orthodox religion in Russia), but because he truly believed in it, he shared with his citizens the belief in those values. 
public. The modern concept of "private life" (as the realm where the morally autonomous individual is "master of himself") did not exist, and in the ancient city-state (the "building block" of the Empire) (Foustel de Coulanges 1864) citizens lived mainly as dedicated members of their community. In Rome in particular, the censors ${ }^{7}$ (magistrates elected every five years) were constantly peering into the life of citizens and their families (the realm of the res privata, which at the time was the closest existing thing to what we call today privacy- very different from it, though) to asses if their dedication to the wellbeing of the res publica (the state) was sufficient. If not, the culprits would be publicly blamed and demoted in Rome's social hierarchy (Paolone 2014, 2016).

All this helps us to understand why the Imperial rituals had an "educational" impact on the population. The rituals themselves (with their "total social fact" apparatus which included architecture and city-planning) forged and shaped the lives of people, which were mainly "public" lives, devoid of that sort of "private backstage" where modern men can take a distance from society (like Guicciardini or Montaigne) and "find themselves", or dissent, as morally autonomous individuals.

\section{Universality of the Empire and of Christia- nity: a look into the Pauline Epistles}

Another important element in the discussion on the Imperial and Christian rituals and their educational aspects, which will follow, is the circumstance that the Roman Empire and Christianity share the concept of universality.

St. Paul of Tarsus, who had a deep understanding of the Roman Empire, its laws, its functioning, its meanings and values, was especially aware of one key aspect of Roman citizenship (which he himself had been awarded.) He was born a Jew, and had been educated according to the rules and values of his ethnic/religious group.

Coming from a religion of the book, he had also been educated formally.

Therefore he had received from the clergy of his ethnic/religious group (which he would call a nation) the kind of formal education that we associate today -mutatis mutandis - with a national culture,

But St. Paul was at the same time a Roman citizen, legally and formally the subject of a wider, all-encompassing universal sovereignty, which awarded him some fundamental rights, such as that of being judged directly by the Emperor, in case he appealed to him. (This prerogative of Roman citizenship he was particularly fond of, and he took advantage of it when in need.)

What especially fascinated St. Paul was the possibility for Roman citizens to maintain their varied ethnic (national) identities and at the same time to be subjects of the universal Emperor.

Until his time, religions like Judaism had been strictly tied to the nation to which one belonged; to be a Jew you had to be circumcised, and the child of a Jewish woman.

7 The censors were magistrates in ancient Rome who were responsible for maintaining the census (which included the distribution of citizens in the social orders), overseeing certain aspects of the government's finances and supervising public morality. Established in the virtuous days of the early Republic, the censorship continued in existence for 421 years, from 443 BC to 22 BC. From Augustus onwards, it was the Emperor who discharged the duties of their office (with some historical discontinuities). 
But this new religion which he was helping to establish - Christianity- couldn't that be conceived in the same universal terms as Roman citizenship? St. Peter (and other members of the early Church) initially thought that you had to be circumcised in order to become a Christian. St. Paul had a different vision (Galatians:5,6): no circumcision was needed to be a Christian (no need to belong to a particular ethnicity). You could be born a Jew and become a Christian, but you could be as well a Greek, a Gaul, a Briton... and at the same time be a member of Christianity (Galatians: 3,28 ). In the vision of St. Paul, the latter had to be a universal religion. As people from the various nations and ethnic groups within the limes could become Roman citizens ${ }^{8}$, and at the same time maintain their original "ethnic" identity ${ }^{9}$, the same could happen with Christianity. This is one of the reasons why the new religion quickly spread in the Empire and, after Constantine,$^{10}$ progressively but almost naturally became the new Roman state religion. In some ways Christianity was the heir to the universality of the Roman Empire. In the Lex Rhodia, Antoninus ${ }^{11}$ had stated that the Roman Emperor was the dominus totius orbis (master of the whole World). In the same way, a few centuries later, Pope Gregory VII ${ }^{12}$ in the Dictatus Papae stated that the Pope was exercising universal sovereignty over souls.

One of the consequences of this kinship is that the Roman Catholic Church is not iconoclastic. Images, symbols, rituals are a pillar of its tradition, as they were in the Roman Empire. Since its origins, the Church educates the universal crowd of the faithful also through art, architecture and rituals (the so-called Biblia Pauperum: the "Bible for the humbles"), exactly like the Roman Empire had done before, with its mulltiethnic citizens.

$8 \quad$ Roman citizenship would be automatically extended to all inhabitants of the Empire only after AD 212. 9 In the typical hierarchical perspective of the Ancient, allegiance to the two co-existing identities cannot be equivalent. In the incipit of the book II of his De legibus, Cicero is discussing with Atticus about the concept of patria (fatherland), which elicits a question from his friend. In spite of his patriotism, Atticus says, Cato was not born in Rome, but in Tusculum. Then he had two patriae? Or is our communis patria the only one? And Cicero responds that he thinks that he and all municipal men (born in cities of the Empire different than Rome) have two patriae: one by birth and one by citizenship. Thus, he claims, we consider as our patria both the place were we were born and the place by which we are adopted. But that patria must be pre-eminent in our affection in which the name res publica signifies the common citizenship of us all. This patria is the one that most deserves our allegiance (Cicero, Leg. 2,5).

10 Constantine the Great was Emperor between 306 and $337 \mathrm{AD}$. He played an influential role in the proclamation of the Edict of Milan in $313 \mathrm{AD}$, which declared religious tolerance for Christianity in the Roman Empire. He joined Christianity on his deathbed and was the first Roman Emperor to convert and be baptized. Christianity became the state religion of the Roman Empire with the Edict of Thessalonica, jointly issued by Theodosius I, Gratian and Valentinian II, in $380 \mathrm{AD}$.

11 Antoninus Pius was Emperor from 138 to 161 AD. He was a good administrator, who expanded free access to drinking water throughout the Empire, encouraged legal conformity, and facilitated the enfranchisement of freed slaves. He built the Antonine Wall in Scotland: the northernmost border of the Roman Empire.

12 Ildebrando da Soana was Pope, with the name of Gregory VII, from 1073 to his death in 1085 $\mathrm{AD}$. He is known for the part he played in the "Investiture Controversy", his dispute with Henry IV, Holy Roman Emperor. Pope Gregory affirmed the primacy of papal authority and the new canon law governing the election of the pope by the College of Cardinals. 


\section{Ceremonial Pedagogy: a universal approach to education}

In the days of the Pagan Roman Empire, neither the universal Roman citizenship, nor its religious side (Roman state religion) were tied to a formal education of the book (Bayet 1957), like for instance Judaism. The Empire had chosen another form of "civic education" for its citizens, based on rituals and images (Zanker 1989), and it never considered the need for an equivalent of today's national school systems. (However, from Vespasian onwards, the function of "primary teachers" operating in the public streets was recognized by the Emperor, who was ready to pay them a salary in case of need -and this was still very different from a state school system) (Levick, 1999).

In my mind, modern national school systems derive from a religion-of-the-book type of formal education. It all started when Luther decided that the faithful must be able to read (in German: a national idiom, and in general, in their vernacular language) in order to interpret the Holy Books. Compulsory primary education partially derives from the consequences of this, and the national school systems of Prussia, Sweden, etc. are partially a secular/nationalist derivation of this concept.

In the universal Roman Empire (which was composed of many different ethnicities, and whose Pagan state religion was not a religion of the book) what was needed to educate all citizens (rich and poor, literate and illiterate) in order to make them subjects of the Emperor was rather another form of collective education. The latter should not be tied to "partial" ethnic cultures or languages, but rather on symbols and actions that could "talk" a universal language to the varied ethnic identities of the citizens, in order to integrate them in this wider universal system, notwithstanding their cultural differences. Of course, various - and sparse- types of formal education were already at work within the Empire (Mohler, 1937), but they were not systematic and organic as they are in modern nation-states.

This universal vocation is one of the reasons why the Roman Empire developed its "educational system" in terms of a ritual apparatus rather than in an academic format. After all, even in the days of its foundation Rome had never been "ethnically homogeneous" but rather composed by at least three distinct ethnic groups, very different from each other: the Latins, the Sabines and the Etruscans (Ramnes, Tities, Luceres). The Etruscans even used a different alphabet! But the three groups could live, thrive and fight (as their neighbor cities learned at their own expense) as one. One of the secrets of such unity and strength was a very effective ritual system, which was educating them to become dedicated and well-organized citizens (Paolone 2014, 2016).

And this is one of the reasons why the Roman Catholic Church made the same choice as that which the Empire had made, over the centuries. The Roman Catholic Church kept speaking to the entire World, persisting with the Imperial idea of teaching the masses through "universal" images, rituals and symbols. For centuries, millions of illiterate people all over the World learned the contents of religion also from paintings, sculptures and by performing rituals (the so-called Biblia Pauperum). The development of the Baroque, in the aftermath of Counter-Reformation, is testimony to the long haul of this concept (Sallman 1996). Even the Encyclical Letter Miranda Prorsus by Pope Pious XII (1957), discussing the mass media, still functions on those same principles. 


\section{From the Roman Empire to an Italian village of today. The implicit educational relevance of a ritual deriving from the past}

Some studies have shown that modern patron saint processions could derive from the Roman imperial ritual of adventus, because the latter inspired successive rituals where Popes, bishops or the relics of saints were transported, or exposed to the worship of the faithful (MacCormack 1972: 747).

This is exactly what happens in the village of Castelfiocco (in Central Italy), where once a year the relics of Pope Alexander I (the fifth Pope after St. Peter, reigning from 105 to $116 \mathrm{AD}$ ) are followed by a stately procession in a tour of the village, during which the gathered inhabitants pay him tribute and worship him. I have studied this ritual ethnographically, in order to understand (as it is somehow derived from the Roman Empire) the meanings of universality/locality it can still convey today. One of the questions of my research was if this procession was a contemporary form of the older imperial ceremonial pedagogy, in order to understand, if possible, its re-location within new meaning systems. Does this sort of ritual still have an "educational" function?

In fact, as we shall see in the following pages, in my fieldwork I have realized that the festival in Castelfiocco is a display of the local hierarchical system of worship which, in the opinion of the interviewed villagers, tells a tale of the conflictual (or at least problematic), relationship between local identity and a wider form of identity, tied to the universal sovereignty (on the souls) of the Roman Catholic Church which, as we have seen, is a form of universal Empire.

In the ritual system that was studied, the perception by the villagers of the relationship of relics of the patron saint brought in procession, to some form of universal sovereignty, seems to be confirmed by the circumstance that the saint carried around in Castelfiocco is a Pope. Not only is the Pope the head of the universal Church, but there is also historical evidence that the adventus of the Roman Emperor, beyond the decadence of the Western Roman Empire, gave way to and was survived by the adventus of the Pope (Montaubin 2009, Meyer-Roux 2011). This creates a phylogenetic tie between the original meaning of the adventus as manifestation of the universal sovereignty of the Emperor (on the bodies) and that of the Pope (on the souls), a tie which is inscribed in the wider context of the power fight between Papacy and Empire in the Middle Ages to affirm themselves as the main universal power, especially after the Dictatus Papae by Gregory VII, in AD 1075 (Rocquain 1872) ${ }^{13}$.

\section{Adventus}

The imperial adventus was a ceremony by which the people of the cities in the Roman Empire represented themselves in a "sensuous way" (MacCormack, 1995), and formalised and aestheticised their social elements via a spatial and visual representation, in a form of ancient "ceremonial pedagogy", which was in fact a form of ritual education (Schriewer 2009).

13 The Pope's claim to some of the universal powers of the Roman Emperor (and the theological/ political disputes on this problem) constitute one of the main themes of medieval Italian history (See: Rocquain 1872, Edwards 2005, Sistrunk 1987, etc.) 
By the act of welcoming the Emperor in a provincial town (but also in Rome, when he came back from war or from a long absence), and by following the stately procession by which he was touring the city, this ceremony was meant, among other things, to create a moment of consensus between the assembled population (Brown 1996: 127-136). It was also meant to display visually, by the physical disposition of the citizens gathered together, some of the values on which the Roman state (and later the Christian society) was based. In this sense, this complex ritual system could be considered as a form of ceremonial pedagogy, but its impact on the attending human groups was much deeper than one could conceive in modern societies.

The main part of the ritual consisted of a stately procession, which has elements in common with two older rituals called amburbium and lustrum, two defensive circular processions (Paolone 2014, 2016). It has also elements in common with the successive processional -and educational- rituals, involving the relics of saints (Brown 1996: 127-136, MacCormack 1972: 747): it was a sort of historical "bridge" between the former and the latter.

By attending the adventus, (and later, the procession of the patron saint) youth in particular was being educated into some of the values which were structuring society (MacCormack 1995). At a time when a national school system did not exist, this could be considered a ceremonial form of civic education. But, as we have seen (Paolone 2014), the meaning of these ceremonies went far beyond this "educational" vision which is more suited for modern societies. The impact of this "ceremonial education" on the Ancient was of a different kind: less rational and more collective and unconscious. It derived mostly from the sensuous impression that it made on the crowd that attended, rather than on the rational solicitation of the individuals (which is instead at the centre of today's educational practices). It made all participants feel part of a community and the catalyzer of this feeling was the physical presence of the Emperor, and later of the Pope or of the relics of the saints (Brown 1996: 127-136).

\section{The premises and structure of the ritual}

In today's Italy, sentiments of national or other forms of universal belonging seem to be weak, compared with other sentiments of local membership. In Central Italy, the village membership seems still to be a strong element of identity. Political studies have been already done on some of the historical reasons of this circumstance (Romanelli 1991: 711720). My fieldwork took place in Castelfiocco ${ }^{14}$, a village of about 9,0oo people located in the border area between Marche and Abruzzi (historically, the border between the State of the Church and the Kingdom of Naples).

The study aims at assessing the informal settings of ceremonial pedagogy, where the local population is exposed to values linked to -or promoting- the sentiment of local (as opposed to universal) membership.

The keystone of this local ideology is the festival of St. Alexander, Martyr and Pope ${ }^{15}$, one of the two main patron saints of Castelfiocco. The festival takes place on August 26, a day entirely devoted to rituals, at a time when usually people are enjoying their summer holiday. August 26 marks the end of this period and it is a sort of final burst of leisure for local people. Of course this is a modern interpretation. In fact the festival of the patron

14 On the demand of fieldwork informants, I have changed the name of the village.

15 The other main patron saint, St. Michael, officially has no procession in Castelfiocco. 
saint has a historic and educational function in the local society. It depicts the local cosmos to the people who participate, it publicly shows the sets of values linked to each of the two main patron saints of the village. These values apparently do not contemplate the intermediate dimension of the nation-state, and locate the village community either in the universal space of Christendom, or they separate the community from the rest of the world in terms of a localist vision which in Italy goes by the name of campanilismo (Palumbo 2003).

As in the adventus ritual from which it derives historically, the procession of the patron saint, where the relics are exposed to the villagers, creates a feeling of general consensus (Brown 1996, MacCormack 1995) during which all members of the community feel part of that community, with an emotional, almost bodily involvement that finds no equivalents in other contemporary social facts.

\section{Mars/St. Michael: the heathenish local hero}

Castelfioccans told me that the local ritual system (the part of the ritual system expressing genuinely local values) has survived for centuries, because it was able to avoid being censored by powerful value systems coming from the outside, such as that of the Church. By using deception, it had managed to transmit to the population the symbols of local belonging, and ideas divergent from the Roman Catholic dogma, by concealing them under devious forms. In this sense, the present study considers especially the way in which Castelfiocco rituals partially conceal the figure of Mars/St. Michael the Archangel, armed guardian, protector of the village and symbol of uncompromising localism. He appears in armour on the crest of the commune, brandishing a sword and a shield. His portrait is posted in most houses and his sculpted effigy stands on the main church's embattled bell tower, since the time of its construction.

Notoriously he is tied to the stubborn local character, which has great affection for the village, is very cautious with strangers, and which is resistant to all forms of power imposed from the outside. To mention a few anecdotes, drawn from field interviews and confirmed by the study of documents, it is known that in the 70s, while Italy was living a season of virulent strikes, the local communist administration of Castelfiocco kept national trade unions out from the local factories, in order to protect production. The then very centralised Italian Communist Party (which conveyed the universal ideology of Marxism) was unable to overcome this resistance, and the local administration kept following its own policy on this and other matters. Besides, emigrants from Castelfiocco, compared to emigrants from other villages in the area, are known to leave home very reluctantly and come back as soon as they can, as fast as they can. The villagers proudly tell the anecdote of a local painter, living in poverty, who in the early 1900 s was eventually appointed director of an important art museum abroad, but refused the job, not to leave his beloved Fatherland.

In the mind of the villagers, this local attitude is embodied by St. Michael, which is also the symbol of an ancient, heathenish form of religious cult which is still incarnated by one of the two brotherhoods still active in the village: the Rosario brotherhood. This ancient brotherhood resides in the Church of the Rosary, but in fact worships the pagan god Mars in the shape of St. Michael (in a way that has some resemblances with the Roman hero worship) (Spaeth 1925). When they parade in processions, the brethren wear an ancient light armour called kardiophylax (because they are warriors). One of the 
archaic attributions of Mars was "god of the surface"; in other words, not only of borders and war, but also of agriculture, and vineyards. At the time of vintage, the brethren buy the best available grapes on the local market and, in their canteen, produce their own superior quality wine (which is used to celebrate mass, but not only that).

The Rosario brethren are the symbol of a different way of living with religion, heathenish and very much centred on the local community, and not very respectful of the universal principles and rules of the Roman Catholic Church.

\section{The cult system of the village}

In fact, the cult system of the village is based on a diad of saints, which are worshipped intra-moenia (within-the-walls). They are the actual protagonists (one officially, the other undercover) of the processional ritual which, like its ancestors in the Roman Empire, is tied to the village topography and monuments: the spaces where the ceremonial pedagogy takes place. In the local perception, even if they have partially disappeared, the walls with which these two saints (and especially St. Michael) are associated are still a very important symbol. In former times, Castelfiocco was strengthened by ramparts, punctuated by seven conspicuous towers, some of which are still visible. Around the beginning of the XIX century the walls had already partly disappeared or had been absorbed into the residences, some of which were built exploiting pre-existing pieces of wall. Castelfioccan families consider it an honour to have a piece of the ramparts incorporated in their houses. The greatest honour is to live inside one of the ancient towers. One of my informants, Mr. Fausto, spent a fortune to restore the tower in which he lives with his extended family, and he proudly stands on its balcony on the occasion of village rituals such as the patron saint procession. The walls are associated with the concept of self-defence. Being a border village, Castelfiocco has been constantly hit by invasions, the transit of armies, sieges and raids. The remains of a labyrinth of tunnels and secret passages are still accessible from the cellars of local homes. Historically, it often happened that Castelfioccans had to retreat inside the ramparts, and leave the land outside of the walls at the mercy of invaders. They thus developed a sort of cynical attitude towards that land. Traditionally, villagers living inside the walls consider with a slight disdain peasants living in the nearby countryside (sometimes they still call them sharecroppers). The ramparts are a structural element of the processional ritual: exactly like in the Roman amburbium, the procession encircles the walls in a rite of protection, in which Mars is "invoked" on the boundary, to defend the Fatherland (Dumézil 1947: 138).

\section{The conundrum of the date: a substitution of saints}

Therefore, the Castelfiocco procession is encircling the ramparts like in the amburbium of the Roman Empire. But in this case, where is Mars? In fact, the village procession is officially dedicated to St. Alexander, Martyr and Pope, but the day of its celebration (August 26) is evidently mistaken. According to the liturgical calendar, his onomastic falls on May 3. August 26 instead is tied to the name of St. Alexander of Bergamo (Istituto Giovanni XXIII della Pontificia Università Lateranense 1961-69: item St. Alexander). I have asked to the informants why they think there is this incongruity. The answer was that "St. Alexander is St. Michael in disguise." 
This answer of the popular wisdom has acquired greater intelligibility after I investigated St. Alexander of Bergamo. According to the Christian tradition, he was a Roman legionary, member of the Theban legion, commanded by St. Maurice, martyred for his faith in the fourth century AD. He is represented in armour, and his images are surprisingly similar to those of St. Michael the Archangel, especially in the eighteenth-century engraving I found frequently in the houses of Castelfiocco.

Therefore St. Alexander of Bergamo has the same name of St. Alexander Martyr and Pope, but has the same aspect of St. Michael the Archangel.

We now return to the statement according to which "St. Alexander is St. Michael in disguise" and try to understand it more in depth.

The procession involves two churches intra-moenia. The first one is the main church, dedicated to St. Michael. Its earliest construction probably dates back to the IX century, but excavations have shown that it is on top of a more ancient building built on the area in which in the Roman age a temple was dedicated to Mars (Palma 1832). According to the locals, the ruins of the latter are still visible in the basement of the bell tower. In the Middle Ages, the main church had the function of being the central building or mastio of the fortified system of Castelfiocco. As can still be seen, the bell tower of the main church has battlements, built according to the rules of military architecture.

The procession has its beginning and end in the main church where, to the right of the altar, the statue that is brought in procession, that of St. Alexander, Martyr and Pope, is guarded. In the church, the relics of the saint, which constitute a central element of the procession, are preserved. There is a mummified arm, dressed in silver, fixed in the action of pointing out the sky in a blessing gesture. In the procession the relic comes ahead of the statue, but it does not seem to be the principal object of the popular veneration. To the left of the altar instead another wooden statue, representing St. Michael in armour, is guarded, opposite to that of St. Alexander.

The other church involved in the procession is that of the Rosario, built in the XIX century on the initiative of the eponymous brotherhood. No particularly important relics are guarded in it. A great fresco in the apse reproduces the functional characters found in the main church: St. Michael and, to the opposite side, the Pope, this time with the semblances of Pius XII.

\section{Highlights of the ritual}

In the church of the Rosario, secondary in importance after the main church, on the morning of the feast of St. Alexander, the confirmands are assembled, and they listen to the last teachings on the sacrament that they are about to receive.

Then, they process to the main church following the bishop who then celebrates the mass, in which youth receive the Confirmation. During the celebration, the bishop sprinkles incense on the wooden statue of St. Alexander. After the ceremony the families disperse and go to celebrate the Confirmation, in their private homes, with a ritual family lunch. One must consider that in the central hours of the day temperature is hot (it is the end of August) and it is better to wait for the cool, around the evening, to be able to follow a procession which lasts over one hour. But this means also that each family celebrates the patron saint in a private banquet (Brown 1996: 55).

Around six o'clock the main procession begins, with a mass in honour of St. Alexander. The bishop does not participate in this celebration, which is focussed entirely on the local 
community (he usually leaves Castelfiocco after the Confirmations). At the end of the mass the relic and the statue of the saint are brought out of the church and the ritual begins, followed by the whole population.

The procession is opened by a boy who carries a small cross. In his group other choirboys march along two lines. Then a deacon brings the relic of the saint, escorted on each side by a town policeman. Finally the wooden statue of the saint, supported on a cart, preceded by the priest and escorted by the local policemen, is propelled by members of the Brotherhood of the Rosario and the Brotherhood of Addolorata. The latter brotherhood, still vital, has its seat near the main church, and for centuries has been in rivalry with the Brotherhood of the Rosario, that instead has its seat in the homonymous church.

The procession makes a complete tour of the village, and ideally following the old village boundaries. The most recent buildings, built in the peripheral zones, are left out.

The whole population takes part to the procession. Many take an active part in following the statue of the saint, others assist from the side of the roads or from the windows and balconies of their houses, decorated for the occasion with special red and yellow cloth.

At the end of the procession, the statue of the saint is brought into the piazza of the belvedere, built above a piece of the old fortifications. From that position the saint attends, together with the assembly, a firework session. The saint, eventually, returns to the main church. Before reentering, the statue is shortly exposed to the believers on the piazza. The priests bless the bystanders, shaking the silver arm of the saint towards them. At this point the band plays a military march and, while local policemen salute and the villagers watch, the statue is brought inside the main church. Then the crowd disperses along the streets of the village, decorated for the festival and filled with fair stands.

\section{Spaces, symbols, and informal education}

Why do Castelfioccans bring in procession St. Alexander instead of the "patron" that the village is celebrating, and which is St. Michael? A possible explanation comes from the consideration that St. Michael is an archangel and therefore has no relics: physical remains of his mortal body that can be worshipped by the believers and from which descend those powers usually associated with relics (Brown 1996: 121).

The Christian procession, of the type that takes place in Castelfiocco, seem to derive from the imperial adventus (MacCormack 1995 : 97-102). In the adventus, the Roman Emperor paraded along the streets of the visited city, followed by a stately crowd of notable and military. In the Christian procession, what is paraded are the relics of a new (in comparison to the Emperor) type of patronus, the patron saint (Webb 1996: 3), with the purpose to create a moment of general consensus among the population (Brown 1996: 128-130). The physical presence of the patronus being needed, a saint with relics seems to be the appropriate choice for the procession.

But, behind the circumstance of the substitution of the two holy patrons, there is also another, deeper symbolic meaning, linked to the perception of the local community in political terms.

As I have already mentioned, in Castelfiocco each of the locally worshipped saints represents a set of values linked either to the universal or to the local, and the public representation in ritual form of the cult of these saints, serves to confirm to the local population and to transmit to the new generations the way that the community has symbolically to relate itself to political spaces: local space and universal space. It is a sort of ritual system of civic education. 
The school system instead teaches youth the affiliation to the nation-state. The Italian school system in particular is born with the unification of the Country (in the second half of the XIX century) with the purpose of "making the Italians" (Soldani, Turi 1993).

The rituals of Castelfiocco transmit values that go back to a more ancient conception. When Italy as a nation did not exist, there were only either various forms of local membership or the universality of the Church, which was modelled on the universality of the Roman Empire. Some of these archaic forms of local membership had their roots in the pagan epoch.

As in the Middle Ages every free city had its patron, often an imported martyr whose relics were preserved in the main church and was regarded as the patron not merely of the church and the diocese, but of the city conceived as a social and political community (Webb 1996: 4), in ancient Italy every community had its local gods. In Castelfiocco there was the cult of Mars, whose altar was probably built under today's main church. It is not our task to prove here if there is a real continuity between the two cults (Warde Fowler 1922: 215-218). What we know is that in Castelfiocco the cult of St. Michael is today still linked to the campanilismo, which is a strong localist vision.

In the pagan epoch, Mars was invoked on the occasion of the processional rituals that encircled the borders of the inhabited area -like the procession called amburbium- to help the community to defend herself from foreigners and enemies (Dumézil 1947: 148149). This action of ritual procession around the community, invoking Mars to protect it, also happened on the occasion of the periodic distribution of the population in the social orders, the census followed by the lustrum ${ }^{16}$. On that occasion the magistrates called censores, officially welcomed the 17 year-old boys into the group of the citizens -and therefore soldiers, by imposing ${ }^{17}$ their hand on them. Today the bishop does something similar with the confirmed: he welcomes them in the adult community of the believers. There is then the procession, but in which St. Michael -another guardian and patron, equivalent to what Mars was in the ancient processions- for some reason cannot openly be invoked.

In his place, another patron saint is officially worshipped: St. Alexander Martyr and Pope.

The relics of the latter were sent to Castelfiocco at the time of the Counter-Reformation. The version orally transmitted is that the saint was given by the Church to the village as patron to save the community from an epidemic of unspecified nature. Why should Rome deprive herself of such a precious relic for the sake of a few remote believers in Castelfiocco? The patron saint they already had was not enough? A hypothesis is that the Church of Rome wanted to replace one cult with another. The principles of CounterReformation included a vision of the cult of saints (Sallmann 1996), in which every pagan-like residual was to be reconsidered. In this sense St. Alexander, being a martyr of the Church of the origins, was a perfect candidate for replacing the heathenish cult of St. Michael.

But above all, St. Alexander was a Pope, symbol of the universality of the Church: an antidote therefore to the local Armed Guardian, protector of the local borders and

16 In the days of the Roman Republic, once every five years the citizens were distributed in the five hierarchical classes which constituted the social orders. In a ritual called census, two magistrates, the censors, decided which class each citizen had to be allocated to, on the basis of his patrimony and of his virtue and patriotism. After that, a sacrifice to Mars and a procession around the community (lustrum) would complete the ritual.

17 Here the term "imposing" is pertinent to the formal management of a ritual; it does not have the connotation of something unwelcome. 
expression of a localist popular religiousness. This is why the relics of St. Alexander were sent to Castelfiocco, exactly like an Emperor or a Pope (in Italian history, two equivalent figures in terms of their universal sovereignty -and this is how they are still percieved by Castelfioccans) in a ritual which was mimicking the imperial/papal adventus: his arrival in the "heathenish" village would re-establish the pre-eminence of the universal over the local, of the imperial authority of the Church over the pagan involution of the enclave.

\section{Conclusion}

Castelfiocco has a ritual system in which some essential values for the community are transmitted to the new generations in an informal and traditional way. These values are not those of the modern Italian nation-state, which are conveyed (as anywhere else in Italy) by the school system and by formal education. On the contrary, in this informal and traditional ritual system the values, tied to local saints, are used as a tool for transmitting something very old but still lively, to the population. The dialectic here seems to be more ancient than that of the locality vs. the nation-state -a topical subject in contemporary Italy (Diamanti 1996; Diamanti, Ceccarini 2006: 21-32; Romanelli 1988: 13-24). We have instead a dialectic between the local community (and its constitutive pagan traditions) and the universality of the Church/Empire. This traditional dialectic between the local and the universal is a topic of renewed interest in our age of globalisation (Paolone 2009: 69-91).

In Castelfiocco, elements of the local geography are used to express the traditional values in a way that speaks effectively to the population in symbolic terms. The procession encircles the ancient boundaries of the village, exactly like the pagan ritual called amburbium. The latter, ancestor of the aforementioned adventus, was a processional ritual under the patronage of Mars, its meaning being that of keeping all external forces, foes and strangers, out of the village (Dumézil 1947: 138). In today's Castelfiocco, the stratification of the two rituals -the older heathenish procession involving Mars/St. Michael and conveying local values, and the adventus involving the Emperor/Pope (his relics) and conveying universal values- is possible because the two rituals are historically tied and one derives from the other. But it is evident that in today's ritual, they intertwine in a way that brings together the two sides of the dichotomy. The universal Pope is welcomed in town with the ritual of adventus. At the same time, the local hero Mars/St. Michael is worshipped with the amburbium ritual, which is (historically and structurally) contained in the adventus.

Mars/St. Michael is today brought in procession disguised under the more acceptable form of St. Alexander, a Pope representing the universality of the Church. In the main church, his statue is kept on the right side of the altar, which in biblical terms means that he is or should be the preferred one. St. Michael, on the contrary, is kept on the left side, and even behind a glass door. On the morning of August 26th, under the supervision of the bishop (representative of the Church of Rome) youth receive the sacrament of Confirmation and are thus accepted in the adult community of believers - a universal one- (become "soldiers of Christ"), therefore they do not parade around the local community as pagan youth, newly awarded with adult status, did in the Roman lustrum, or Roman citizens/soldiers did in amburbium. No circular movement here (the pagan circular vision of time, as with St.Augustine), no mimicked circular border-tracing ${ }^{18}$,

18 Both lustrum and amburbium were processions around the community, during which Mars was invoked as protector. The circular, stately procession mimicked the act of ploughing a furrow, which was the 
just a straight procession from the smaller church to the main church. A non-circular procession, modeled on the Christian linear, eschatologic conception and more similar to the adventus. It is there that the universality of the Church is actually celebrated, in a lively, contemporary sacrament such as the Confirmation, which ties the local youth to a universal community. It is a lesser procession, though, if we compare it to the main event, attended in the evening by the whole local population (and without the bishop -not an indigenous power) that proceeds along a wide, all-encompassing, circular path, thus reproducing the traditional pagan scheme of the defensive processional ritual. It is an archaic scheme representing values of closeness and exclusiveness that are in contrast with those of universalism, expressed by Catholicism.

But in the final system, the two dimensions are brought together in a stratified, complex ritual that can be read from different perspectives and which speaks differently to different sorts of audiences. Foreigners (and the official Catholic hierarchy) may just see the part where the Pope, in the form of relics, is welcomed by the villagers as a symbol of the universal Church. Local campanilisti instead use all this as a cover for perpetrating, undisturbed, the worship of their patron Mars/St. Michael, and for showing to young generations what this cult means and how it should be performed.

The Castelfiocco procession, with its images, symbols, rituals, testifies to continuity from the Roman Empire, to the Roman Catholic Church of what I have called (in the beginning of this paper) the "non iconoclastic" tradition of symbolic action. Still today (at least in processions), the Church teaches the faithful by using those same tools and instruments which, already in the Roman Empire, had shown they were able, among other things to transmit, to culturally heterogeneous masses, a sentiment of universal belonging. It is similar to the sentiment which allowed the long lasting internal cohesion of the Roman Empire which positively impressed historians like Gibbon ${ }^{19}$, and which was not to be repeated in subsequent Empires. Therefore, the secret of the cohesion of an Empire can be looked at also by studying its ritual system where, in the stratified rites of ceremonial pedagogy, we may find hints about the crucial dialectic between its universal and local dimensions.

\section{Appendix: a few notes on fieldwork}

My field research in Castelfiocco spans three festivals, from 2014 to 2017. The fieldwork was preceded by preliminary research, and was completed by periods of residence in the village, as a guest of informants and their families, for a total of over six months. I not only observed the rituals, their preparatory stages and their aftermath, but I regularly attended the meetings of the two brotherhoods (including one "winemaking" session by the Rosary brotherhood). I also attended catechism sessions before the sacrament of Confirmation. My main research tool was participant observation. But I systematically interviewed villagers involved in the festival, transcribed the interviews (Levy, Hollan, 1998) and indexed some recurrent themes and terms, which I then analysed and clarified in the light of socio-historical knowledge (from bibliography and from documents) on what I believe to be the "parent forms" of the studied rituals (Dumont, 1987).

basic protection of the Roman military camp and of the Roman city (the foundation ritual of the cities started with the ploughing of a furrow).

19 Gibbon observed that the provinces scarcely considered their own existence as distinct from the existence of Rome (Gibbon 1776). Furthermore, it was the admirable longevity of the Roman Empire, not its caducity, that demanded inquiry. In spite of this, he entitled his work: The history of the decline and fall of the Roman Empire. 
In my fieldwork, I tried to unearth aspects of the traditional social order of the village community, and my intent was somehow that of making cultural persistence visible, at least in terms of the displacing of traditional forms in a new set of meaning. On the other hand, I did not study the dialectic between the local and the global only for its own sake, but in the first place because it is embedded in the ritual, and has ties with the theme of cultural persistence (or better: the relationship between the present, with living forms from the past) and ceremonial pedagogy.

Speaking about the relationship of my research to the work of other ethnographers, some of the features I have mentioned until now can be found in what has been named "Mediterranean ethnography" (Peristiany 1965; Goddard, Llobera \& Shore 1994, etc.).

In this sense, like early "Mediterraneanists" I am (at least in this research) less prone than other ethnographers to abandon the community study approach, and rather inclined to hold on to a focus on rural village communities, conceptualized as microcosms of traditional culture. In other words, the ritual system in Castelfiocco is, under some aspects, a bounded field-site (Candea, 2007).

Like some early Mediterraneanists (du Boulay, 1974:3), my aim in the village was partially that of studying the rituals, values and attitudes which could be derived from a long tradition and which, even in present times, sustain Castelfioccans in a sense of purpose and destiny.

But Castelfiocco is not immune from "globalisation", and therefore the debates on ethnography which have exposed the limits of bounded fieldwork, are relevant to my research (Marcus, 1995; Hannerz, 1998). The village has a small number of immigrants from non-European countries. But, at the moment, their presence has not yet affected the system of brotherhoods and processions. Neither has the integration of the village into the bureaucratic nation-state (and consequently into the EU) and in regional/national/ global economy, weakened the tightness of the rites. On the contrary, the studied ritual system seems to survive properly because it is a symbolic vindication of locality against other forms of sovereignty.

Nevertheless, in my research there is also an implicit element of "multi-sitedness", which is somehow embedded in the ritual system itself: the procession is composed of different symbolic layers, tied either to a local or to a universal dimension, or to some intermediate positions (e.g. the "compromise" resulting from the intertwining of the previous two). The layers (and their different symbolic values) intertwine within the structure which is being studied. By trying to de-structure and analyse it, I am implicitly doing a sort of multi-sited study ${ }^{20}$ (a form of the comparative approach "within" the field and not across cases, that we can infer, inter alia, from Clifford Geertz) (Geertz, 1973: 26). Here the different "sites" are not intended in mere geographical terms, but they coincide with different historical actors implied in the ritual (intended also in terms of the "vantage point" tied to each of them: the Roman Empire, the Roman Catholic Church of Counter-Reformation, the Church of today, the heathenish local community, etc.).

What is being presented in this paper is only a part of the research, which will be soon published in its entirety.

20 Considering that the main focus of the research is that of comparative education, I have already experienced this "embeddedness of multiple sites within one system", when I have researched on returnees from international study exchanges (Paolone, 2013). In that case, the biographical experience of the returnee (intended as a case-study) contained the encounter of two different cultures, which could be conceptualised in terms of multi-sitedness of the research (even if the physical fieldwork had been limited to the homecoming of students and its implications). 


\section{References}

Ando, C. (2000). Imperial Ideology and provincial loyalty in the Roman Empire. Berkeley: University of California Press.

Archer, M. (1979). Social origins of educational systems. London: Sage.

Brezzi, P. (1959). I comuni medioevali nella storia d'Italia. Torino: Eri.

Brown, P. (1996). Le culte des saints. Paris: Cerf. (The Cult of Saints, Chicago: University of Chicago Press).

Constant, B. (1819). De la liberté des Anciens comparée à celle des Modernes.

Cowen, R. (2010). Transfer, translation, transformation. In A.R. Paolone (ed.), Education Between Boudaries, Padova: Imprimitur.

Diamanti, I. (1996). Il male del Nord. Lega, localismo, secessione. Roma: Donzelli.

Diamanti, I., Ceccarini L. (2006). Il tramonto del localismo. liMes, rivista italiana di geopolitica, 2, 21-32.

Dumézil G. (1947). Tarpeia, cinq essais de philologie comparée indo-européenne. Mythes romains III. Paris: Gallimard.

Dumont, L. (1966). Homo hierarchicus. Paris: Gallimard.

Dumont, L. (1987). La Tarasque. Essai de description d'un fait local d'un point de vue ethnographique, Paris : Gallimard

Edwards, M.J. (2005). Constantine's Donation to the Bishop and Pope of the City of Rome. The Journal of Theological Studies, new series, 56(1), 115-121.

Farmer, D.H. (1997). Dictionary of Saints. Oxford: Oxford University Press.

Foustel de Coulanges, N.D. (1864). La citè antique. Paris : Hachette.

Geertz, C. (1973). The Interpretation of Cultures. Selected Essays. New York: Basic Books.

Gibbon, E. (1776-1789). The history of the decline and fall of the Roman Empire.

Goddard, V. A., Llobera, J. R., Shore, C. (eds.) (1994). The Anthropology of Europe. Identities and Boundaries in Conflict. Oxford/ Washing-ton D.C.: Berg.

Hannerz, U. (1998) Transnational Research. In R. H. Bernard (ed.), Methods in Cultural Anthropology. Walnut Creek, London, Delhi: Sage, 235-256.

Hardt, M., Negri, A. (2000). Empire. Cambridge, MA: Harvard University Press.

Herzfeld, M. (1987). Anthropology through the Looking-Glass. Ethnography in the Margins of Europe. Cambridge: Cambridge University Press.

Jaynes J. (1977). The origin of consciousness in the breakdown of the bicameral mind. Boston: Houghton. 
Levick, B. (1999). Vespasian, London \& New York: Routledge

Levy, R.L., Hollan, D.W. (1998). Person-Centered Interviewing and Observation. In H. Russel Bernard (ed.), Handbook of Methods in Cultural Anthropology, (333-364) Lanham: Alamira Press.

Istituto Giovanni XXIII della Pontificia Università Lateranense (1961-69). Bibliotheca Sanctorum. Roma: Città Nuova. Vol.1.

MacCormack, S.G. (1972). Change and Continuity in Late Antiquity. The Ceremony of the "Adventus". Historia: Zeitschrift für Alte Geschichte, 21(4), 721-752.

MacCormack, S.G. (1995). Arte e cerimoniale nell'antichità. Torino: Einaudi. (Art and Ceremony in Late Antiquity: University of California Press).

Marcus, G. E. (1995). Ethnography In/Of the World System: the Emergence of Multisited Ethnography. Annual Review of Anthropology, 24, 95 - 117.

Marrou, H.I. (1948). Histoire de l'éducation dans l'Antiquité. Le monde Romain. Paris: Seuil

Meyer-Roux, K. (2011). The Entry of Clement VIII into Ferrara: Donato Rascicotti's Triumph. Getty Research Journal, 3, 169-178

Montaubin, P. (2009). Pater Urbis et Orbis. Les cortèges pontificaux dans la Rome Médiévale (VIIIe-XIVe siècles). Rivista di storia della Chiesa in Italia, 63(1), 9-47.

Mohler, S.L. (1937). The Iuvenes and Roman Education. Transactions and Proceedings of the American Philological Association. 68, 442-479.

Novoa, A., Yariv-Mashal, T. (2003). Comparative research in education. A mode of governance or a historical journey? Comparative Education, 39(4), 423-438.

Palma, N. (1832). Storia ecclesiastica e civile della regione più settentrionale del Regno di Napoli. Teramo: U.Angeletti. Vol.1.

Palumbo, B. (2003). L'UNESCO e il campanile. Antropologia, politica e beni culturali in Sicilia orientale. Roma, Meltemi.

Paolone, A. (2009). Educazione comparata e etnografia, tra globalizzazione e postmodernità. Roma: Monolite.

Paolone, A. (2013). Chiavi di lettura dell'esperienza soggettiva dei returnees. Processi acculturativi, rapporti con i pari e con gli insegnanti. In Roverselli, C., Paolone, A.R. (eds.) Competenze Trasversali. Valutazione e valorizzazione delle esperienze di studio all'estero. Colle Val d'Elsa: Fondazione AFS Intercultura

Paolone, A. (2014). Citizenship, Values and Social Orders. The Assessment System of Census and Ritual Education in Ancient Rome. In L. Vega (ed.), Empires, PostColoniality and Interculturality. New Challenges for Comparative Education. Rotterdam: Sense.

Paolone, A. (2016). L'educazione del cittadino attraverso la distribuzione della popolazione nella gerarchia sociale, nella Roma dei primi secoli. I problemi della pedagogia, 62(1), 107-126 
Peristiany, J. G. (1965). Honour and shame in a Cypriot highland village. In J. G. Peristiany (ed.), Honour and shame. London: Weinfeld \& Nicholson.

Pini, A. I. (2000). Citta, comuni e corporazioni nel Medioevo italiano. Bologna: Clueb.

Porciani, I. (1997). La festa della nazione. Rappresentazione dello Stato e spazi sociali nell'Italia Unita. Bologna: Il Mulino.

Robertson, W. (1820). Storia del regno dell'imperatore Carlo V. Milano: Vincenzo Ferrario (The History of the Reign of the Emperor Charles V, Edinburgh: Balfour)

Rocquain, F. (1872). Quelques mots sur les « Dictatus Papae ». Bibliothèque de l'École des chartes. 33, 378-385.

Romanelli, R. (1991). Le radici storiche del localismo italiano. Il Mulino, 4, 711-720.

Romanelli, R. (1988). Poteri locali. La nazionalizzazione della periferia. Casi e prospettive di studio. Meridiana, 27, 13-24.

Sallmann, J.M. (1996). Santi barocchi. Modelli di santità, pratiche devozionali, comportamenti religiosi nel Regno di Napoli dal 1540 al 1750. Lecce: Argo.

Schiavone, A. (1998). Italiani senza Italia. Torino: Einaudi.

Schriewer, J. (2009). Ceremonial pedagogy in revolutionary societies. Public staging and aesthetic mass inculcation in Meiji Japan, the early Soviet Union and post1910 Mexico. In J.Schriewer (ed.), Remodelling social order through the conquest of public space: myths, ceremonies and visual representations in revolutionary societies. Leipzig: Leipziger Universitätsverlag.

Sistrunk, T.G. (1987). Obligations of the Emperor as the Reverent Son in Dante's Monarchia. Dante Studies (with the Annual Report of the Dante Society), 105, 95-112.

Soldani, S., Turi, G. (eds.) (1993). Fare gli Italiani. Scuola e cultura nell'Italia contemporanea. I: lo Stato nazionale. Bologna: Il Mulino.

Spaeth, J.W. (1925). Roman Hero Worship. The Classical Journal. 20(6), 352-355.

Warde Fowler, W. (1922). The Religious Experience of the Roman People. London: Macmillan.

Webb, D. (1996). Patrons and Defenders. The Saints in the Italian City-States. London and New York: Tauris.

Zanker, P. (1989). Augusto e il potere delle immagini. Torino: Einaudi. (Augustus und die Macht der Bilder. München: Oskar Beck, 1987) 